\title{
Effect of Different Establishment Methods and Varieties on Yield, Quality and Nutrient Uptake of Kharif Finger Millet (Eleusine coracana (L.) Gaertn.)
}

\author{
P.P. Sarawale*, V.A. Rajemahadik, G.B. Shendage, Bheru Lal Kumhar and A.D. Mote \\ Department of Agronomy, College of Agriculture, Dr. Balasaheb Sawant Konkan Krishi \\ Vidyapeeth, Dapoli- 415712, Maharashtra, India \\ *Corresponding author
}

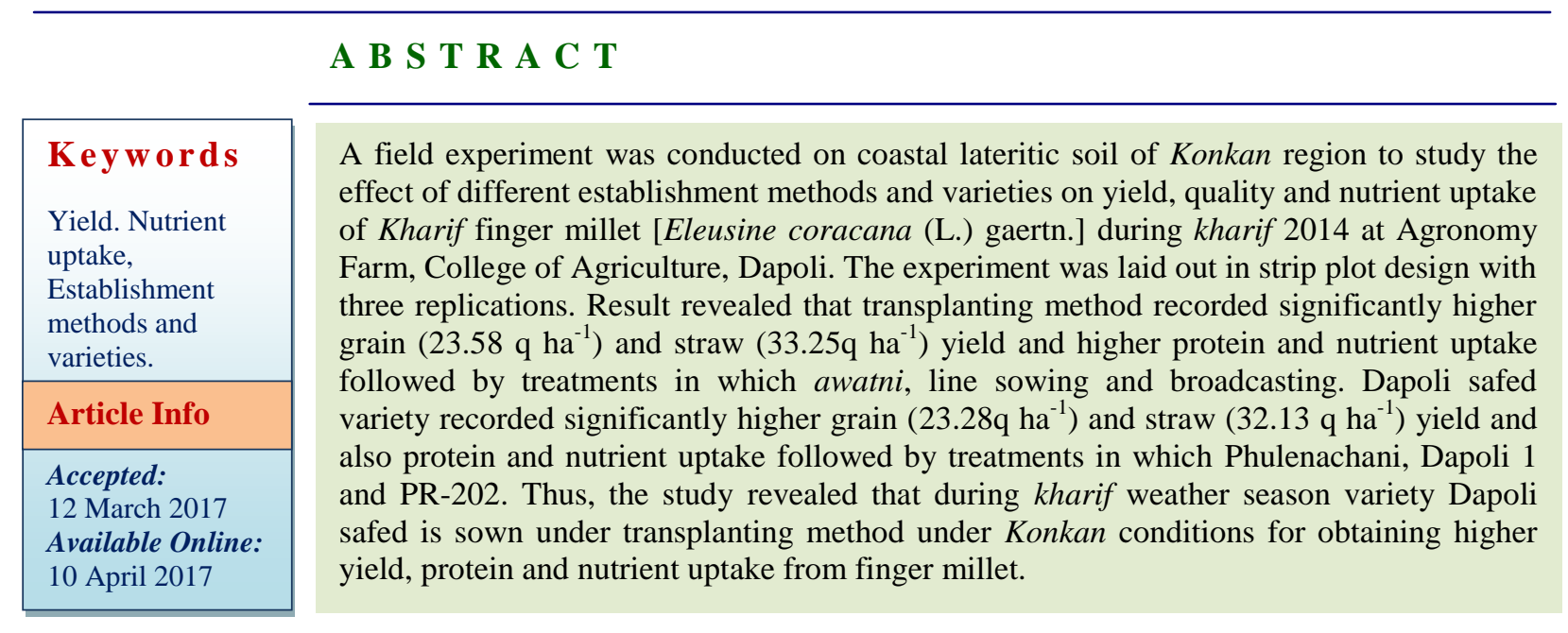

\section{Introduction}

Finger millet (Eleusine coracana (L.) Gaertn.) is an important food grain crop of semi-arid tropics particularly of India and East Africa. This crop is generally grown on the moderate hill slop where rice cultivation is not possible. It requires minimum rainfall of around 350$400 \mathrm{~mm}$ for successful cultivation but can be grown successfully in the areas receiving rainfall up to $1000 \mathrm{~mm}$. It can be grown on a wide range of soils from very poor to very fertile. However, well drained loam or clay loam soils are best for finger millet cultivation. The grain contain $9.2 \%$ proteins, $1.29 \%$ fats, $76.32 \%$ carbohydrates, $2.2 \%$ mineral, $3.90 \%$ ash, $0.33 \%$ calcium. Vitamin $\mathrm{A}, \mathrm{B}$ and phosphorous are also present in smaller quantity, iodine content in finger millet is reported to be the highest among food grain. Finger millet taste better than most other cereals. It has no major pest problem and so can be stored cheaply for a long time. The straw has an immense utility as fodder for both draught and milch animal.

It makes good fodder and contain up to $61 \%$ of total digestible nutrients (Upadhyaya, 2006). Another cause for low yield of finger millet is lack of suitable sowing methods and varieties in konkan condition. Therefore, to exploit high yielding potential of finger millet the field experiment was conducted. 


\section{Materials and Methods}

A field experiment was conducted at department of Agronomy, Dr. B.S.K.K.V., Dapoli during Kharif season of 2014 to study the response of finger millet (Eleusine coracana (L.) Gaertn.) varieties to different establishment methods under Konkan condition. The experiment was laid out in a strip plot design with three replications. The main plot treatments were four different varieties, viz., Dapoli safed $\left(\mathrm{V}_{1}\right)$, Dapoli 1 $\left(\mathrm{V}_{2}\right)$, Phulenachani $\left(\mathrm{V}_{3}\right)$ and PR-202 $\left(\mathrm{V}_{4}\right)$. The sub plot treatment comprised of four establishment methods, viz., transplanting $\left(\mathrm{M}_{1}\right)$, line sowing $\left(\mathrm{M}_{2}\right)$, awatni $\left(\mathrm{M}_{3}\right)$ and broadcasting $\left(\mathrm{M}_{4}\right)$. Thus, there were in all 16 treatment combinations. The plot of $4.2 \mathrm{~m} \times$ $3.0 \mathrm{~m}$ size were prepared and marked manually. In transplanting and awatni methods used 30 days old healthy seedling for sowing and in line sowing and broadcasting methods used bold and healthy seeds for sowing. The calculated quantity of $\mathrm{N}$ and $\mathrm{P}_{2} \mathrm{O}_{5}$ were applied through urea and Single Super Phosphate, respectively. Seeds were properly covered with soil in direct seeded methods to avoid damage from rainfall and birds. Weeding was done properly two times in direct seeded methods and one time in transplanting and awatni methods. In order to assess the effect of different treatments on the growth and yield of finger millet crop biometrical observations were recorded.

\section{Results and Discussion}

Effect of Finger millet varieties on yield and quality

The data in table 1 yield attributes revealed that the variety Dapoli safed recorded higher grain and straw yield of finger millet. The result revealed that significantly higher yield attributes were observed in Dapoli safed and their by grain yield $\left(23.28 \mathrm{q} \mathrm{ha}^{-1}\right)$ and straw yield (32.13 q ha $\left.{ }^{-1}\right)$ over Phulenachani $\left(V_{3}\right)$,
Dapoli $1\left(\mathrm{~V}_{2}\right)$ and PR-202 $\left(\mathrm{V}_{4}\right)$. The present result consonance with those of Yadav et al., (2014) in rice.

The data presented in table 1, variety Dapoli safed recorded higher protein content (9.09 $\%$ ) in grain of finger millet followed by Phulenachani, Dapoli 1 and PR-202 which were at par with each other except PR-202. Thus, PR-202 recoded significantly lowest protein content $(7.21 \%)$ in grain of finger millet than all other varieties.

\section{Effect of Establishment methods on yield and quality}

The data in table 1 revealed that transplanting method of establishment recorded significantly higher grain $\left(23.58 \mathrm{q} \mathrm{ha}^{-1}\right)$ and straw yield $\left(33.25 \mathrm{q} \mathrm{ha}^{-1}\right)$ over rest of the establishment methods followed by awatni (21.35 and $\left.30.08 \mathrm{q} \mathrm{ha}^{-1}\right)$. The increase in grain yield recorded under transplanting over awatni, line sowing and broadcasting of seeds were $10.44,19.15$ and 24.23 per cent, respectively. As a matter of fact the yield of unit area basis was higher with lower plant population. In other words lower yield plant ${ }^{-1}$ was not nullified because of high number of plant in broadcasting, line sowing and awatni. The present results are in consonance with those of Ravi (1984) and Newase et al., (1995) in finger millet and Tippangoudar (2009) in proso millet, respectively. Transplanting $\left(\mathrm{M}_{1}\right)$ of finger millet recorded higher straw yield $\left(33.25 \mathrm{q} \mathrm{ha}^{-1}\right)$ over awatni $\left(\mathrm{M}_{3}\right)$, line sowing $\left(\mathrm{M}_{2}\right)$ and broadcasting $\left(\mathrm{M}_{4}\right)$.

In the methods of establishment awatni recorded numerically higher value of protein content $(8.35 \%)$ in grain of finger millet followed by transplanting, line sowing and broadcasting which were at par with each other. Broadcasting method recorded lower protein content $(7.47 \%)$ in grain of finger millet than rest of the methods. 
Effect of finger millet varieties on nutrient uptake

The data presented in table 2 showed that the Dapoli safed content higher $\mathrm{N}, \mathrm{P}$ and $\mathrm{K}$ in grain and straw of finger millet followed by Phulenachani, Dapoli 1 and PR-202 which were at par within themselves except $\mathrm{N}$ content in grain which was significantly higher than other treatments. Varieties showed more growth and yield attributes is due to more nutrient uptake from soil which affect on yield. Since, uptake of nutrients in finger millet is a function of grain and straw yield and their nutrients content, the improvement in the content of these nutrients coupled with significantly increased grain and straw yield increased uptake of nutrients. The result resembles the finding of Nain et al., (2013) in rice.

\section{Effect of establishment methods on nutrient uptake}

The data presented in table 2 showed that Transplanting and awatni recorded almost identical and higher $\mathrm{N}, \mathrm{P}$ and $\mathrm{K}$ content in grain and straw of finger millet over line sowing and broadcasting. This might be due to the fact that the crop absorbed proportionately higher amount of $\mathrm{N}, \mathrm{P}$ and $\mathrm{K}$ due to their higher availability under comparatively lower plant population and less competition among the plants for growth resources.

Table.1 Effect of different establishment methods and varieties on yield and quality (protein content) of Kharif finger millet

\begin{tabular}{|c|c|c|c|}
\hline Treatments & $\begin{array}{l}\text { Grain yield } \\
\left(\mathbf{q} \mathbf{h a}^{-1}\right)\end{array}$ & $\begin{array}{c}\text { Straw yield } \\
\left(\mathbf{q} \mathbf{h a}^{-1}\right)\end{array}$ & $\begin{array}{l}\text { Protein content } \\
\text { in grain }(\%)\end{array}$ \\
\hline \multicolumn{4}{|l|}{ Varieties } \\
\hline $\mathbf{V}_{\text {1-Dapolisafed }}$ & 23.28 & 32.13 & 9.09 \\
\hline $\mathbf{V}_{2}$-Dapoli 1 & 20.40 & 28.75 & 7.69 \\
\hline $\mathbf{V}_{3 \text {-Phule nachani }}$ & 21.13 & 30.00 & 7.78 \\
\hline $\mathrm{V}_{4^{-}}$PR-202 & 18.90 & 27.17 & 7.21 \\
\hline F. test & Sig. & Sig. & Sig. \\
\hline S.Em. \pm & 0.19 & 0.34 & 0.51 \\
\hline C.D. at $5 \%$ & 0.65 & 1.17 & 1.78 \\
\hline \multicolumn{4}{|c|}{ Establishment methods } \\
\hline M-Transplanting & 23.58 & 33.25 & 8.33 \\
\hline $\mathbf{M}_{2 \text { - Line sowing }}$ & 19.79 & 27.92 & 7.63 \\
\hline M3-Awatni & 21.35 & 30.08 & 8.35 \\
\hline M M- Broadcasting & 18.98 & 26.79 & 7.47 \\
\hline F. test & Sig. & Sig. & Sig. \\
\hline S.Em. \pm & 0.69 & 0.66 & 0.50 \\
\hline C.D. at $5 \%$ & 2.06 & 1.96 & 1.48 \\
\hline \multicolumn{4}{|l|}{ Interaction effect } \\
\hline F. test & N.S. & N.S. & N.S. \\
\hline S.Em. \pm & 2.31 & 2.72 & 0.90 \\
\hline C.D. at $5 \%$ & - & - & - \\
\hline General mean & 20.93 & 29.51 & 7.94 \\
\hline
\end{tabular}


Table.2 Effect of different establishment methods and varieties on nutrient uptake of Kharif finger millet

\begin{tabular}{|c|c|c|c|c|c|c|}
\hline \multirow{2}{*}{ Treatments } & \multicolumn{2}{|c|}{$\mathrm{N}$ uptake $\left(\mathrm{kg} \mathrm{ha}^{-1}\right)$} & \multicolumn{2}{|c|}{ P uptake (kg ha $\left.{ }^{-1}\right)$} & \multicolumn{2}{|c|}{ K uptake $\left(\mathrm{kg} \mathrm{ha}^{-1}\right)$} \\
\hline & Grain & Straw & Grain & Straw & Grain & Straw \\
\hline \multicolumn{7}{|l|}{ Varieties } \\
\hline $\mathbf{V}_{1}$-Dapoli safed & 30.45 & 20.14 & 4.92 & 4.30 & 19.82 & 49.53 \\
\hline $\mathbf{V}_{2 \text {-Dapoli } 1}$ & 25.52 & 19.44 & 4.66 & 3.95 & 19.29 & 49.35 \\
\hline $\mathbf{V}_{3 \text {-Phule nachani }}$ & 26.03 & 19.70 & 4.72 & 4.13 & 19.60 & 49.45 \\
\hline $\mathbf{V}_{4^{-}}$PR-202 & 24.93 & 18.45 & 4.28 & 3.64 & 18.40 & 49.23 \\
\hline F. test & Sig. & Sig. & Sig. & Sig. & Sig. & Sig. \\
\hline S.Em. \pm & 1.17 & 0.63 & 0.26 & 0.13 & 0.36 & 0.03 \\
\hline C.D. at $5 \%$ & 4.06 & 2.20 & 0.91 & 0.45 & 1.24 & 0.10 \\
\hline \multicolumn{7}{|c|}{ Establishment methods } \\
\hline $\mathbf{M}_{1-\text { Transplanting }}$ & 27.81 & 21.23 & 5.56 & 4.87 & 22.64 & 52.53 \\
\hline M2- Line sowing & 26.56 & 19.65 & 4.46 & 3.90 & 18.29 & 53.70 \\
\hline $\mathbf{M}_{3-\text { Awatni }}$ & 27.55 & 20.85 & 5.11 & 4.23 & 20.00 & 55.60 \\
\hline M4- Broadcasting & 25.02 & 16.01 & 3.45 & 3.01 & 16.18 & 35.73 \\
\hline F. test & Sig. & Sig. & Sig. & Sig. & Sig. & Sig. \\
\hline S.Em. \pm & 1.69 & 0.61 & 0.25 & 0.10 & 0.59 & 0.04 \\
\hline C.D. at $5 \%$ & 5.04 & 1.82 & 0.74 & 0.29 & 1.76 & 0.13 \\
\hline \multicolumn{7}{|l|}{ Interaction effect } \\
\hline F. test & N.S. & N.S. & N.S. & N.S. & N.S. & N.S. \\
\hline S.Em. \pm & 4.92 & 1.72 & 0.94 & 0.33 & 2.09 & 0.09 \\
\hline C.D. at $5 \%$ & - & - & - & - & - & - \\
\hline General mean & 26.74 & 19.44 & 4.65 & 4.0 & 19.28 & 49.39 \\
\hline
\end{tabular}


Transplanting increased uptake of $\mathrm{N}, \mathrm{P}$ and $\mathrm{K}$ higher over awatni, line sowing and broadcasting of seeds. Since uptake is a function of grain and straw yield and their nutrient content, the improvement in content of these nutrients coupled with increased grain and straw yield increased the uptake of nutrients substantially. These results resemble the findings of Nanjappa et al., (1987) in finger millet and Singh et al., (2006) in rice.

In conclusion, from the results of the present investigation, it can be concluded that for obtaining higher yield, quality and nutrient uptake from finger millet variety Dapoli safed be sown under transplanting method during kharif season.

\section{References}

Nain Singh. 2013. Root growth, yield and NPK uptake of rice (Oryza sativa L.) varieties grown by system of rice intensification with varying planting geometry and weed management practices. Ann. Agric. Res., New Series, 34(1): 26-35.

Nanjappa, H.V., Hosmani, M.M. and Chetty, T.K.P. 1987. Nutrient uptake by crop and weeds as influenced by crop weed competition under different cropping system in finger millet. Mysore J. Agri. Sci., 21(2): 140-144.

Newase, V.B., Thorat, S.T. and Chavan, S.A.
1995. Effect of methods of planting and fertilizer application on the yield of kharif ragi. J. Indian Soc. Agric. Res., 13(2): 151-152.

Ravi, N. 1984. Influence of planting time and method of establishment on the growth and yields of rainfed ragi. Mysore $J$. Agri. Sci., 21(4): 3.

Singh, Parmeet and Singh, S.S. 2006. Effect of establishment methods, fertility level and weed management practices on aromatic rice. Indian J. Agron.., 51(4): 288-292.

Tippanagoudar, P.G. 2009. Studies on comparative performance of proso millet (Panicum miliaceum L.) under methods of sowing and weed management. M.Sc. Agri.) Thesis submitted to the Dr. B.S.K.K.V., Dapoli (unpublished).

Upadhayay, P.N., Dixit, A.G., Patel, J.R. and Chavda, J.R. 2001. Response of summer pearl millet (Pennisetum glaucum) to time and method of planting, age of seedling and phosphorus groen on loamy sand soil of Gujarat. Indian J. Agron., 46(1): 126130.

Yadav, L. and Meena, R.N. 2014. Performance of aromatic rice genotypes as influenced by integrated nitrogen management. Indian J. Agron., 59(2): 251-255.

\section{How to cite this article:}

Sarawale, P.P., V.A. Rajemahadik, G.B. Shendage, Bheru Lal Kumhar and Mote, A.D. 2017. Effect of Different Establishment Methods and Varieties on Yield, Quality and Nutrient Uptake of Kharif Finger Millet (Eleusine coracana (L.) Gaertn.). Int.J.Curr.Microbiol.App.Sci. 6(4): 1285-1289. doi: https://doi.org/10.20546/ijcmas.2017.604.157 